\title{
The Malacosporean Myxozoan Parasite Tetracapsuloides bryosalmonae: A Threat to Wild Salmonids
}

\author{
Arun Sudhagar ${ }^{1,2}$, Gokhlesh Kumar ${ }^{1, * \mathbb{D}}$ and Mansour El-Matbouli ${ }^{1}$ (D) \\ 1 Clinical Division of Fish Medicine, University of Veterinary Medicine, Vienna 1210, Austria; \\ Arun.Sudhagar@vetmeduni.ac.at (A.S.); Mansour.El-Matbouli@vetmeduni.ac.at (M.E.-M.) \\ 2 Central Institute of Fisheries Education, Rohtak Centre, Haryana 124411, India \\ * Correspondence: Gokhlesh.Kumar@vetmeduni.ac.at
}

Received: 4 November 2019; Accepted: 20 December 2019; Published: 23 December 2019

\begin{abstract}
Tetracapsuloides bryosalmonae is a myxozoan parasite responsible for proliferative kidney disease (PKD) in a wide range of salmonids. PKD, characterized by high mortality and morbidity, is well known for affecting aquaculture operations and wild salmonid populations across Europe and North America. The life cycle of T. bryosalmonae revolves around freshwater bryozoan and salmonid fish hosts. In recent years, T. bryosalmonae has been reported among wild salmonids from the European countries where it has not been reported previously. T. bryosalmonae is believed to be a possible reason for the diminishing wild salmonid populations in the natural water bodies of many European countries. Climate crisis driven rising water temperature can further accelerate the distribution of T. bryosalmonae. Expansion of the geographical distribution of T. bryosalmonae may further advocate the decline of wild salmonid populations, especially brown trout (Salmo trutta) in their habitats. Mathematical models are used to understand the pattern and distribution of T. bryosalmonae among the host in the natural water bodies. The present manuscript not only summarizes the incidences of $T$. bryosalmonae among the wild salmonid populations, but also discusses the contemporary understanding about the development of T. bryosalmonae in its hosts and the influences of various factors in the spread of the disease in the wild.
\end{abstract}

Keywords: brown trout; bryozoan; climate change; myxozoan; proliferative kidney disease

\section{Introduction}

Tetracapsuloides bryosalmonae is a myxozoan parasite belonging to class Malacosporea and is well known for causing proliferative kidney disease (PKD) in salmonids [1]. The parasite life cycle exploits two different host species, an invertebrate bryozoan host and a vertebrate salmonid fish host (Figure 1) [2-5]. PKD in fish results in the enlargement of kidney and spleen, glomerulonephritis, anemia, ascites, exophthalmia, pale gills and darkened skin in the infected fish depending upon the severity. PKD alone can cause high mortality while secondary infections can speed up the death process and increase mortality even further [6]. T. bryosalmonae poses a serious threat to farmed and wild salmonids across Europe and North America. T. bryosalmonae is one of the major factors associated with the decline of endemic brown trout (Salmo trutta) population in the streams of Alps [7-10]. 


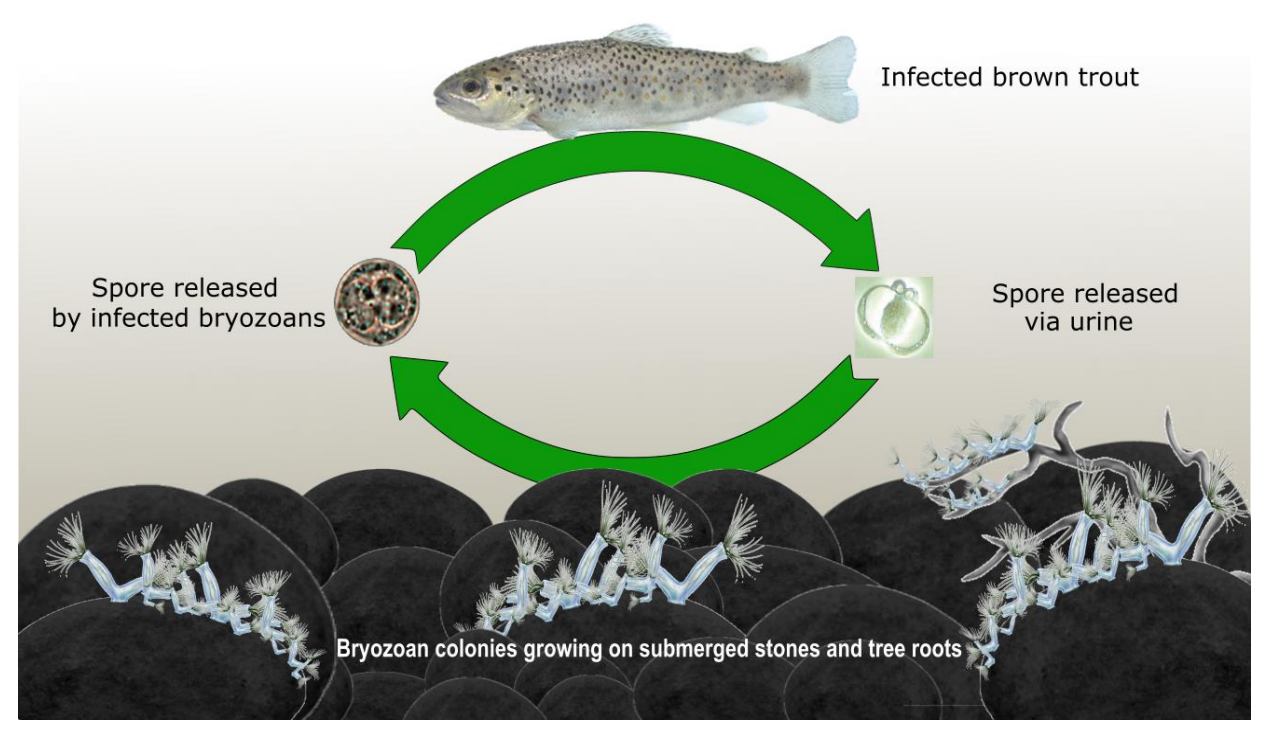

Figure 1. Tetracapsuloides bryosalmonae life cycle in salmonid fish host and invertebrate bryozoan host in wild environment. Climate change associated rising water temperature can enhance the proliferation of the parasite in both hosts. Waterfowls are suspected to be the long-distance vector of the parasite.

In recent years, T. bryosalmonae has been reported from new geographical locations from wild salmonids. This can be due to the spread of the parasite to new locations or due to the emergence of PKD outbreaks by the already existing parasite in that aquatic ecosystem unnoticed for a long period. However, T. bryosalmonae incidences are threatening as it can lead to massive fish kill events in natural water bodies affecting endemic fish population. T. bryosalmonae was responsible for the mass mortality of salmonids, particularly wild mountain whitefish (Prosopium williamsoni) from the Yellowstone river, Montana, USA [11]. This incidence led to the shutdown of $300 \mathrm{~km}$ river segment to public access for a certain period of time, which subsequently affected local tourism and the associated economy [12]. It is important to highlight that high-water temperature and low water flow cognate with this fish kill incidence.

The impact of T. bryosalmonae parasite on the protracted decline of wild fish populations is often more challenging to study as the infection dynamics is influenced by rising water temperature related to emerging climate change. Laboratory experiments depict that rising water temperature can enhance parasite production in both bryozoan and fish host [13-16]. Moreover, salmonids are cold water fish that are sensitive to higher temperatures, which may further aggravate the disease condition in the wild. Juvenile and adult salmonids prefer to occupy streams with temperature ranging between $13-18{ }^{\circ} \mathrm{C}$ and the water temperature approximately above $23-25^{\circ} \mathrm{C}$ is fatal for salmonids [17]. Researchers also suspect waterfowl and common carp for the spread of $T$. bryosalmonae to naive locations. This review discusses about the T. bryosalmonae development in its host, emerging incidences of the parasite, role of climate change and the biological vectors that enhances the spread of the parasite among wild salmonids.

\section{Tetracapsuloides bryosalmonae}

Despite the fact that PKD like condition was first described in early 1920's from Germany in rainbow trout (Oncorhynchus mykiss) [18], the disease condition was named as proliferative kidney disease in early 1970's defining the main clinical features [19]. Transmission electron microscopic studies in 1985 revealed that a myxozoan parasite is the causative agent of PKD [20]. In the late 1990s, the involvement of an invertebrate bryozoan host was discovered in the life cycle of this myxozoan parasite [21]. The parasite was taxonomically distinguished from Buddenbrockia sp. and 
eventually named as Tetracapsuloides bryosalmonae under a new myxozoan class malacosporea $[1,22,23]$. Molecular phylogenetic studies suggest that myxozoans are evolutionarily primitive, morphologically degenerated cnidarians and their polar capsules are comparable with cnidarians nematocyst [24]. Two clades of T. bryosalmonae stemming from North America and Europe were identified. Interestingly, the North American clade of parasites was isolated from southern Europe. Scientific evidence suggests aquatic birds to be the possible vector for transporting the parasite between the continents [25].

The freshwater bryozoan acts as a definitive host and the fish acts as an intermediate host for T. bryosalmonae [26]. Freshwater bryozoans commonly occur in rivers, ponds and lakes. They live in colonies on the surfaces of submerged rocks, plants, roots and branches of trees. Bryozoans are suspension feeders and their colonies propagate either by budding new zooids or by means of asexual reproductive seed-like structures called statoblasts. Statoblasts remain dormant and germinate to form a new colony under favorable conditions [27]. Bryozoan species of Cristatella mucedo, Pectinatella magnifica, Plumatella rugosa, Plumatella sp., and Fredericella sultana serve as hosts for T. bryosalmonae [28]. However, F. sultana is the most preferable host for T. bryosalmonae [29]. The route of parasite entry in the bryozoan host is not known but it is believed that the parasite might enter the host while the zooids feed on suspended materials in water [25]. After entry, the parasite goes into a cryptic stage developing a covert infection in the bryozoa. Following this, the parasite develops an overt infection by entering into a presaccualar stage $(8-13 \mu \mathrm{m})$ which is observed swirling within the body cavity of the infected bryozoa [2,30]. Finally, the parasite develops to an amoeboid stage forming a prominent mature parasite spore sac $(350 \mu \mathrm{m})$ having about 2800 to 4000 spores depending on size and packing density $[22,31]$. The mature spores having four polar capsules are then released by the infected bryozoan colonies, which infect salmonids (Figure 2).

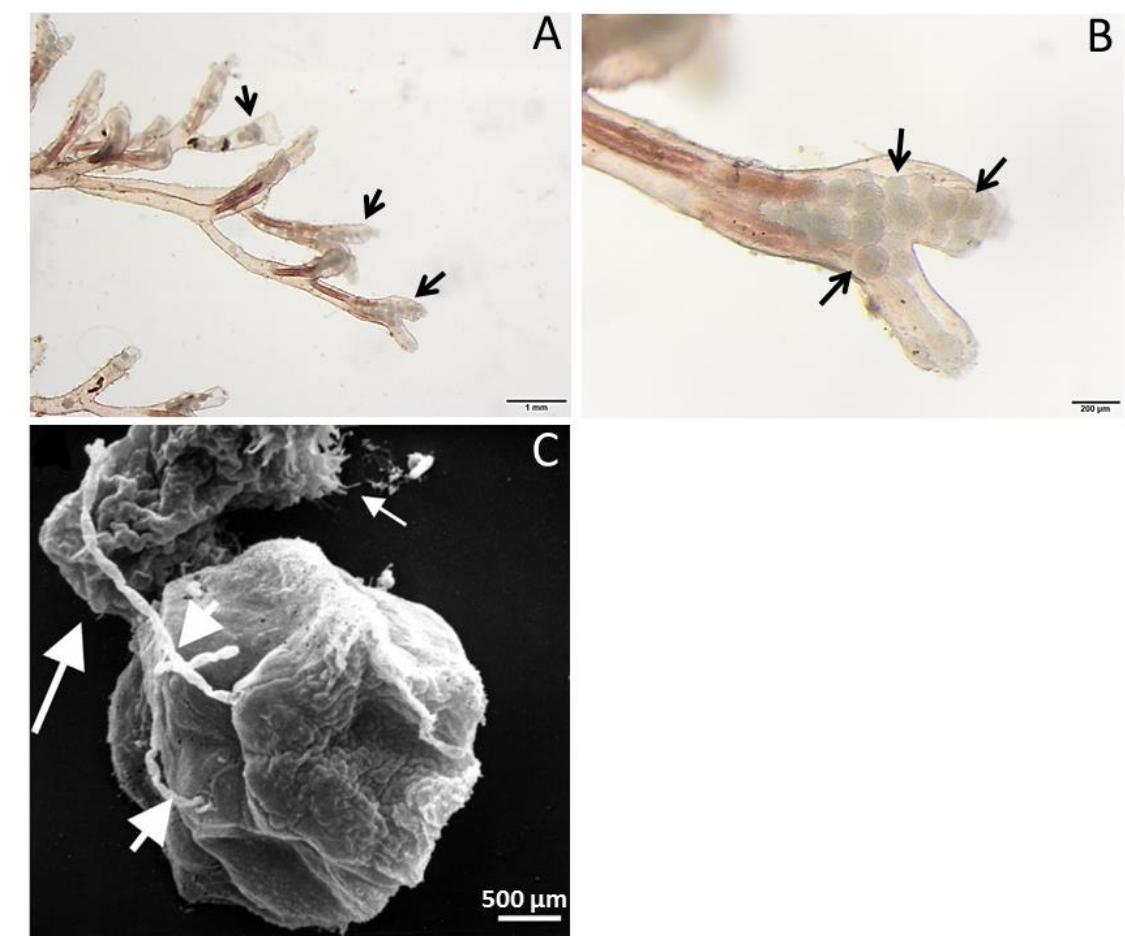

Figure 2. Tetracapsuloides bryosalmonae infection in bryozoan colonies and its scanning electron microscopy image. (A) - Laboratory-reared bryozoan Fredericella sultana colony infected with T. bryosalmonae and its body cavity filled with parasite sacs (arrows). (B)-Numerous mature parasite sacs (arrows) inside a bryozoan zooid that could readily release into the water and infect salmonids. (C) - Top view of a spore with its four polar capsules covered by valve cells. Short arrows: two polar filaments being fired. Large arrow: sporoplasm leaving the spore at the bottom side. Small arrow: formation of pseudopodia. The image was obtained from Grabner and El-Matbouli [5]. 
Salmonids are the prime fish host for T. bryosalmonae infection. The parasite penetrates via gill epithelium of the fish and enters the circulatory system which disperses the parasite to various internal organs, principally to kidney [5]. Moreover, multiplication of extrasprogonic stages of parasite happens between the interstitium of kidney tissue and the extrasprogonic stages move to the lumen of kidney tubules where they differentiate into pseudoplasmodia. Single cellular amoeboid spore having two polar capsules develops within the pseudoplasmodia $[20,32,33]$. The developed parasites are then released via urine of infected fish that further infect the bryozoan host. The infected fish exhibits severe inflammatory responses leading to anemia, enlargement of kidney and spleen, consecutively leading to $100 \%$ mortality (Figure 3). Furthermore, granulomatous responses are often observed in chronic infection. Rainbow trout and brown trout are the most studied salmonid species to T. bryosalmonae infection [34]. Rainbow trout have not co-evolved with the European strain of T. bryosalmonae as infected rainbow trout cannot release mature parasite spores that can infect the bryozoan host. However, fish-to-bryozoan transmission is possible in brown trout and brook trout (Salvelinus fontinalis) $[2,35,36]$. In a recent study, brown trout recovered from PKD infection was able to release viable spores of T. bryosalmonae even after five years of infection [37]. This clearly demonstrates that brown trout recovered from PKD could act as a reservoir for T. bryosalmonae dispersal in the wild.

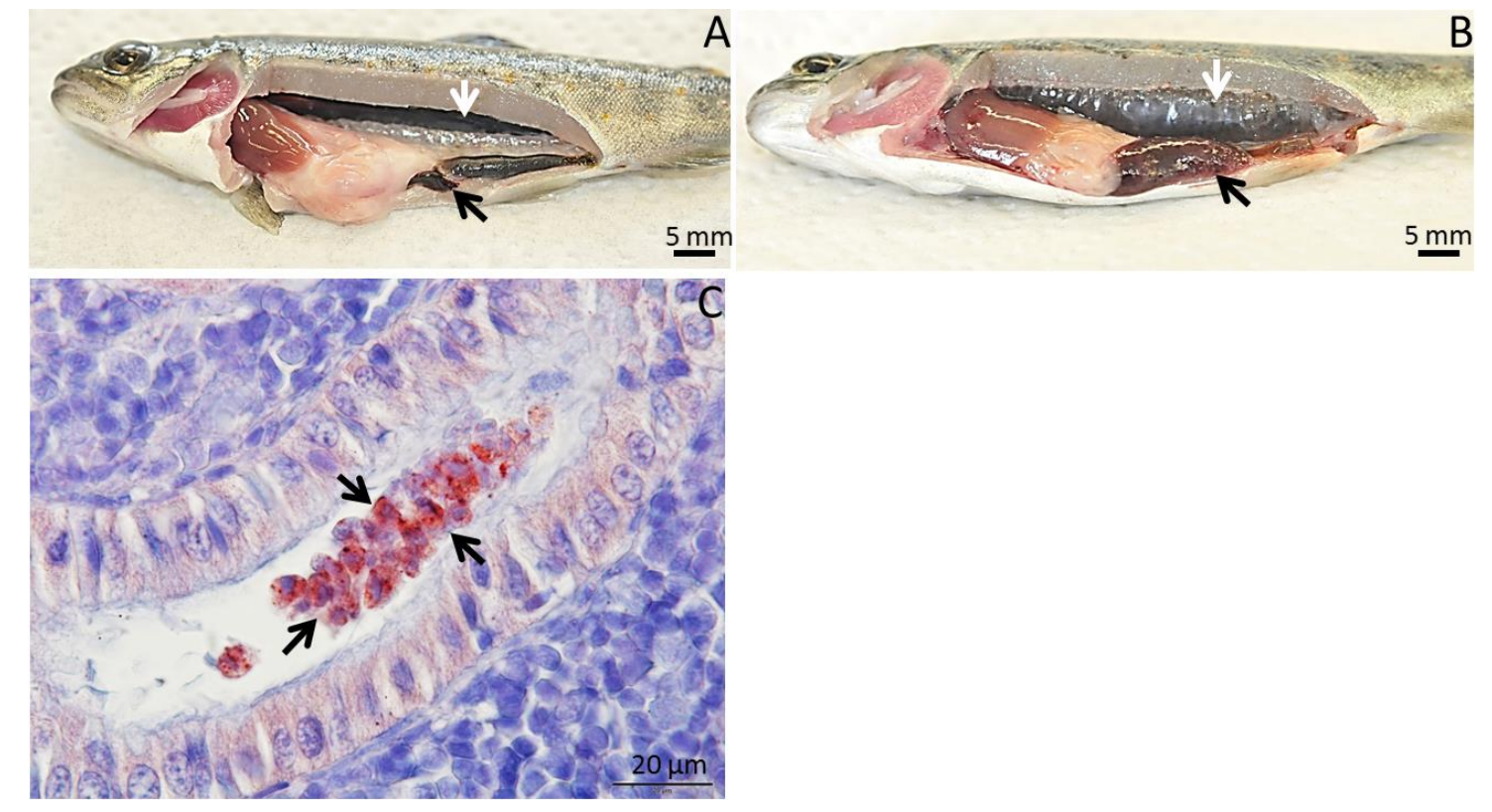

Figure 3. Clinical signs of proliferative kidney disease in brown trout. (A) Uninfected control brown trout shows normal kidney (white arrow) and spleen (black arrow). (B) Tetracapsuloides bryosalmonae infected brown trout shows clinical signs such as renal hypertrophy (white arrow) and splenomegaly (black arrow). (C) Intraluminal sporogonic parasite stages of T. bryosalmonae (arrow) inside the renal tubule of infected brown trout. Parasites were visualized by immunohistochemistry using anti-T. bryosalmonae monoclonal antibody and counterstained with hematoxylin (C image was obtained from Kumar et al. [35]).

\section{Geographic Distribution of T. bryosalmonae and Impact of PKD among Wild Salmonids}

Apart from their endemic habitats, salmonids are distributed all across the globe by human intervention in the wild and captive environments. T. bryosalmonae has been reported from both farmed as well as wild salmonid populations in many countries of Europe and North America [6,38]. Even though pike (Esox lucius) has been reported for PKD by various investigators, the results are still questionable and have not been confirmed by molecular or ultrastructural evidence. With the development of better diagnostic techniques, the rapid expansion of the salmonid aquaculture industry, global warming and other anthropogenic activities, the geographical distribution of T. bryosalmonae 
is likely to expand [39-41]. Recent reports suggest that T. bryosalmonae may be associated with the decline of wild brown trout population in the European rivers, which has created more interest among researchers in the exploration of this parasite in wild salmonid populations $[9,10,40-47]$. Brown trout is endemic to Europe [48] and it is the widely reported fish species for T. bryosalmonae infection in the wild. Apart from brown trout, T. bryosalmonae has been reported from other salmonids from the wild (Table 1).

Early investigators speculated for the presence of infectious agent causing PKD in the rivers, which supply water to commercial aquaculture facilities with PKD outbreaks. Interestingly, PKD positive wild fish were found in those rivers [49-53]. Probably, the parasite might have spilled over from the wild to cultured salmonids held in aquaculture facilities. T. bryosalmonae-associated wild salmonid decline have been observed in many countries across northern hemisphere. However, T. bryosalmonae is one among many factors that are responsible for the wild salmonid decline. In most case, bryosalmonae-associated wild salmonid decline are protracted and mortalities are unnoticeable in the natural habitat. Early investigators used microscopical observations for the detection of the parasite and with the improvement of molecular diagnostic techniques, screening of T. bryosalmonae was possible even in cryptic infections. A wide survey was done in the early 2000s by sampling wild salmonids for T. bryosalmonae infection in the alpine rivers of Switzerland and the results of the study revealed that the geographical distribution of $T$. bryosalmonae could be much wider than anticipated [45]. From there on, more and more researchers explored the impact of T. bryosalmonae in wild salmonid populations and their association with salmonid stock depletion in European riverine systems $[40-45,47,54,55]$. T. bryosalmonae associated wild brown trout decline is well documented in Switzerland where T. bryosalmonae-positive sites were found all across the country [46,47]. Interestingly, T. bryosalmonae infections were widely observed in brown trout sampled below $800 \mathrm{~m}$ above the mean sea level. Furthermore, above this altitude, only a small amount of T. bryosalmonae positive brown trout were observed in the rivers drained by shallow lakes. This relationship between altitude and T. bryosalmonae incidence in wild brown trout could be associated with water temperature [45]. Evidence suggests that water temperature plays a pivotal role in affecting host-pathogen interaction during T. bryosalmonae infection in wild brown trout, thereby promoting the decline of their stocks in their habitat [56]. In addition, widespread distribution of bryozoan colonies covertly infected with T. bryosalmonae was observed from the rivers of England [57]. Comparison between wild brown trout and disease-free brown trout reared in the water enzootic for T. bryosalmonae showed that there were no prominent differences in disease prevalence between wild and captive trout [58]. Prevalence studies of renal myxosporidiosis in wild brown trout sampled from English rivers provided prevalence estimates for T. bryosalmonae and Chloromyxum schurovi [59]. Likewise in Austria, T. bryosalmonae is widely recorded among the wild brown trout population and could be a possible reason for their decline in the Austrian rivers [10].

A considerable reduction in wild Atlantic salmon (Salmo salar) population was observed in a Norwegian river due to T. bryosalmonae infection [55]. In a recent study, a very high prevalence of T. bryosalmonae was observed in Atlantic salmon, Arctic charr (Salvelinus alpinus) and brown trout from the rivers along the Norwegian coast [60]. Similarly, T. bryosalmonae incidences were associated with rising temperatures along with the decline of wild fish populations such as Arctic charr in Iceland [43]; brown trout and Atlantic salmon in Denmark [61]; pink salmon in Canada [62]; brown trout in Estonia [42,63]; brown and rainbow trout from Slovenia [64]; brown trout and grayling in Finland [65]. In a recent study, European whitefish (Coregonus lavaretus) infected with T. bryosalmonae were isolated from the lakes of Finland [66]. A detailed information of T. bryosalmonae reports from wild salmonids is presented in Table 1.

In the summer of 2016, a fish kill incident associated with T. bryosalmonae at Yellowstone river, Montana, USA affected local tourism, livelihood and recreational activity [11]. The initial estimates suggest a total economic output of the county reduced by about $\$ 359,750$ to $\$ 523,815$ [12]. The endemic salmonid, mountain whitefish were the most affected species in this incident. Local officials and 
anglers have reported a decline in the catch of mountain whitefish in the past decade and the reason for the catch reduction is unknown [67]. Detailed studies are needed to evaluate the catch decline of mountain whitefish keeping T. bryosalmonae as a prime suspect.

Apart from this, PKD has been reported in countries such as France [25,68], Italy [25,69,70], Spain [71], Ireland [72] and Czech Republic [73] from salmonid aquaculture facilities. Recently, a novel culture medium, Bryozoan Medium $\mathrm{C}$ was developed for the cultivation and maintenance of bryozoan host under laboratory conditions [74]. This may facilitate the maintenance of T. bryosalmonae parasite life cycle (Figure 1) collected from different geographical locations under laboratory condition for conducting further research. The resulting outcome will help in understanding the geographical origin, genetic differences, and infectivity of different strains of T. bryosalmonae parasite. Furthermore, environmental DNA (eDNA) monitoring [75,76] and lateral flow dipstick [77] based detection of T. bryosalmonae are valuable tools for pathogen surveillance in the wild. 
Table 1. Report of Tetracapsuloides bryosalmonae infection from wild salmonids.

\begin{tabular}{|c|c|c|c|}
\hline Reported Year & Fish Species & Country & Reference \\
\hline 1981 & Grayling & United Kingdom & [49] \\
\hline 1982 & Brown trout & United Kingdom & [50] \\
\hline 1984 & Rainbow trout & USA & [52] \\
\hline 1991 & Brown trout and grayling & United Kingdom & [51] \\
\hline 1992 & Cutthroat trout & USA & [78] \\
\hline 1995 & Kokanee salmon and chinook salmon & Canada & [53] \\
\hline 2002 & Brown trout & United Kingdom & [79] \\
\hline 2002 & Rainbow trout, brown trout and grayling & Switzerland & [54] \\
\hline 2004 & Brown trout $^{+}$and cutthroat trout ${ }^{++}$ & United Kingdom $^{+}$, Switzerland $^{+}$and USA $^{++}$ & [25] \\
\hline 2007 & Atlantic salmon & Norway & [55] \\
\hline 2007 & Brown trout & Switzerland & [46] \\
\hline 2007 & Brown trout & Switzerland & [47] \\
\hline 2008 & Brown trout, rainbow trout and brook trout & Switzerland & [45] \\
\hline 2008 & Brown trout & United Kingdom & [59] \\
\hline 2010 & Arctic charr and brown trout & Iceland & {$[43]$} \\
\hline 2010 & Brown trout and Atlantic salmon & Denmark & [61] \\
\hline 2010 & Pink salmon & Canada & {$[62]$} \\
\hline 2013 & Brown trout & Switzerland & {$[56]$} \\
\hline 2014 & Brown trout & Estonia & {$[42]$} \\
\hline 2014 & Brown trout and rainbow trout & Slovenia & {$[64]$} \\
\hline 2015 & Brown trout & Switzerland & [58] \\
\hline 2016 & Mountain white fish, rainbow trout, brown trout and cutthroat trout & USA & {$[11,12]$} \\
\hline 2016 & Brown trout & Austria & [9] \\
\hline 2017 & Brown trout and grayling & Finland & [65] \\
\hline 2017 & Atlantic salmon, Arctic charr and brown trout & Norway & [60] \\
\hline 2017 & Brown trout & Estonia & [63] \\
\hline 2018 & Brown trout and rainbow trout & Austria & [10] \\
\hline 2018 & European whitefish & Finland & {$[66]$} \\
\hline 2019 & Chum salmon & USA (Alaska) & {$[80]$} \\
\hline 2019 & Brown trout & Germany & [81] \\
\hline
\end{tabular}

${ }^{+}$and ${ }^{++}$corresponds to the fish group and the country on the same row. 


\section{Effect of Temperature on T. bryosalmonae Infected Bryozoan and Fish Host}

In recent years, scientists have investigated the impact of climate change-associated temperature rise on infectious diseases that could significantly affect host-parasite relationship $[56,82,83]$. Scientific evidence collected from streams of Switzerland suggests that rising temperatures could expand the geographical distribution of T. bryosalmonae [45]. The rising water temperature can enhance the geographic distribution of $T$. bryosalmonae by enhancing the growth of bryozoan colonies thus more host biomass available for parasite life cycle [39], and similarly infected bryozoans and carrier fish could release more parasites at warmer temperature providing more infectious material to the environment for the spread [14-16].

Bryozoans tend to multiply and establish prominent colonies at higher water temperature $\left(20^{\circ} \mathrm{C}\right)$ [39]. In addition, higher water temperature $\left(20^{\circ} \mathrm{C}\right)$ tends to enhance overt infection and release of the parasite spores from the infected bryozoan colonies into the water bodies [16]. PKD outbreaks in fish are seasonal and are directly related to the water temperature. High temperature enhance T. bryosalmonae multiplication inside the fish host, and the clinical symptoms of PKD and associated mortalities are often observed when water temperature goes beyond $15{ }^{\circ} \mathrm{C}[6,13-15]$. Brown trout reared at a water temperature of $15^{\circ} \mathrm{C}$ showed a higher prevalence and intensity of parasites than trout maintained at $12{ }^{\circ} \mathrm{C}$ [84]. Rainbow trout exposed to water enzootic to T. bryosalmonae during winter months are found to be more resistant to PKD-associated mortalities in the following summer when the water temperature rises [85-87].

In recent years, $T$. bryosalmonae has been reported from northern latitudes, which may be affiliated with warmer waters $[42,43,55,65]$. In addition, it is possible that the parasite might have already been in those environments for a long time undiagnosed. For example, in a recent study archived samples of Sockeye salmon (Oncorhynchus nerka) reared in net-pens in a freshwater lake of Alaska collected in 1997 were found positive for T. bryosalmonae [80]. As the climatic patterns are expected to alter in the upcoming years, the geographical distribution of T. bryosalmonae might expand to newer regions. Apart from rising temperature, eutrophications of water bodies are often linked with T. bryosalmonae infection in the wild [38]. The availability of more food for bryozoans in eutrophic water bodies enhances their growth $[31,88]$ which in turn facilitates higher host availability for parasite propagation.

Fish are cold-blooded (also referred to as ectothermic or poikilothermic) animals and their immune responses are temperature dependent [89-92]. Immune suppression associated with PKD due to the decrease of phagocytic activity by granulocytes is considered to cause a secondary infection in rainbow trout [93]. The swelling and proliferation of interstitial tissue of the kidney associated with PKD are due to immune responses by the fish against the pathogen. This immune reaction leads to the regression of kidney glomerulus and tubules, which may affect the osmoregulatory capacity and hematopoiesis of fish [14]. Infiltration of macrophages and necrotic cell debris are seen in the infected kidney [94,95]. Flow cytometry analysis showed the dominance of lymphocytes in the kidney of infected rainbow trout [93]. A significant B cell/antibody response and involvement of $\mathrm{T}$ helper cell activity are associated with the pathogenesis of PKD in rainbow trout $[96,97]$. Higher temperatures $\left(18^{\circ} \mathrm{C}\right)$ can influence the immune system of fish and can accelerate the clearance of T. bryosalmonae parasite in rainbow trout [94]. Laboratory experiments suggest that even a slight temperature difference may influence the immune strategy of the fish host against the parasite. At cooler temperatures $\left(12{ }^{\circ} \mathrm{C}\right)$ the immune system of the rainbow trout host tends to tolerate the parasite, whereas a subtle increase of temperature $\left(15^{\circ} \mathrm{C}\right)$ redirects the host immune strategy towards resisting the parasite [96]. Studies on T. bryosalmonae infected brown trout from the wild showed that clinical symptoms of PKD are more strongly associated with kidney hyperplasia rather than with parasite load [98]. In addition to this, the defense strategy in different fish host varies, rainbow trout shows resistance whereas brown trout exhibits tolerance towards T. bryosalmonae [99]. Similarly, humoral immune response and endocytic pathway genes were downregulated profoundly in brown trout and, in contrast, they were upregulated in rainbow trout [100]. It is clear that temperature has a significant role in the selection of immune strategy of the fish hosts against $T$. bryosalmonae. In a recent experiment, protease genes involved in collagen catabolic 
process were downregulated during sporogenesis of T. bryosalmonae in brown trout [101]. Whereas, few collagen catabolic genes were upregulated in rainbow trout during recovery phase of PKD [102]. The collagen catabolic protease may play a crucial role in the persistence or clearance of T. bryosalmonae in brown trout and rainbow trout respectively. However, further studies on collagen catabolic protease are needed to gain insights on the difference in infection and co-evolution pattern of T. bryosalmonae observed between brown trout and rainbow trout.

\section{Aquatic Birds and Common Carp as Vectors of Tetracapsuloides bryosalmonae}

Waterfowls are well known to transport aquatic invertebrates and their eggs from one geographical location to another through both internal and external transportation [103]. Aquatic fowls could ingest T. bryosalmonae-infected statoblasts and introduce them into a naive habitat through their fecal matter or some statoblasts have hooks by which they attach themselves to the fowl feathers [2]. Phylogenetic studies hypothesize that the Northern American clade of T. bryosalmonae parasite might be transported to certain parts of Europe by waterfowls [25]. Besides, a recent laboratory experiment suggests that common carp (Cyprinus carpio) could also disperse infectious statoblasts by ingesting and subsequently excreting them [104]. Common carp are known to migrate up and down stream throughout the year up to $890 \mathrm{~km}$ [105]. However, they have different habitat preferences than brown trout. In fact, common carp typically dwell in lotic or slowly flowing waters, whereas brown trout prefer cold, lentic water bodies. Further studies are thereby needed to enhance our understanding of common carp and other potential fish species as vectors of statoblast carrying T. bryosalmonae in the wild. It is possible that aquatic fowl and some migratory fish species like common carp could be a potential vector, which aid in the geographical expansion of T. bryosalmonae. It is interesting to note that vertical transmission of T. bryosalmonae is possible through infected statoblasts of bryozoa and the parasite could remain in dormancy inside the statoblasts [106]. In addition, the changing climate pattern may possibly alter the movement of waterfowls which may further contribute to the spread of T. bryosalmonae [26].

\section{Modelling Studies}

Epidemiological models could be used effectively in predicting, preventing and controlling disease outbreaks [107]. Moreover, it may help government agencies to take policy decisions in cases of aquatic animal health management emergencies. The decline of native brown trout in the rivers of Switzerland was assessed using Bayesian probability network and this model aided in site-specific assessment of brown trout population [8]. This study used various variables such as gravel bed conditions, water quality, disease incidences including PKD, water temperature, habitat conditions, stocking practices, angler catch, and flood frequency. State-space models were developed for PKD aiming in understanding the spatio-temporal variation of $T$. bryosalmonae prevalences and fish abundance. This model could predict disease severity based on temperature regimes and could help with further understanding of the disease transmission [108]. The model was further improved into a comprehensive spatially predictive framework which could identify the key factors in propelling disease patterns in the wild fish population [109]. Case-study application of the developed model serves as an effective tool to predict and control the spread of disease in the wild [110].

Furthermore, a statistical model was employed in the evaluation of the factors yielding differences in relative parasite load and health damage among different $T$. bryosalmonae infected fish populations [63]. In this study, the disease severity was found to be higher in the warmer river than the colder one. Interestingly, the genetic variance for disease traits was higher in the brown trout dwelling in warmer river (maximum observed temperature $23.3^{\circ} \mathrm{C}$ ), whereas the genetic variance for parasite load was observed to be higher among the brown trout of cold river (maximum observed temperature $20.3^{\circ} \mathrm{C}$ ). Moreover, it is predicted that the variation in environmental factors may severely affect the evolution of the fish host towards the resistance and tolerance against the parasite. 


\section{Conclusions}

In the past two decades, T. bryosalmonae has emerged as a threatening parasite that can decline wild salmonid populations. Routine population assessment of wild salmonids are necessary in the waters enzootic for T. bryosalmonae that may help to devise wild fish stock conservation strategies. PKD-recovered brown trout act as a carrier of T. bryosalmonae in the wild and shed the parasite for a very long period. This facilitates the T. bryosalmonae parasite to persist and establish itself in a wider geographical region. As aquatic fowl and common carp are hypothesized as vectors dispersing T. bryosalmonae parasite to different geographical locations, detailed interdisciplinary investigations are necessary to understand vector ecology, biology and impact of climate change on vector-borne transmission. T. bryosalmonae-infected trout are susceptible to secondary infection by opportunistic pathogens, which can even lead to mass mortality events in natural water bodies, particularly in the summer season. Temperature is known to influence the host-pathogen interaction of T. bryosalmonae parasite in its hosts. However, in natural ecosystems, climate change-driven stressors other than temperature as well as multiple-parasitism may also influence their interaction. Therefore, it is essential to conduct experiments to understand the influence of multiple factors and their interaction mimicking the natural environment on the host-parasite dynamics. Furthermore, next-generation sequencing based omics studies can help for the better understand of the host-parasite interaction and to explore the single nucleotide polymorphisms associated with the host resistance to the parasite. Likewise, it is necessary to characterize the strain variations of T. bryosalmonae parasite isolated from different geographical locations and study its interaction with different salmonid hosts. The screening of T. bryosalmonae using eDNA can serve as a promising tool to understand the abundance and distribution of the parasite in the riverine ecosystem. The host-parasite relationship of T. bryosalmonae is dynamic and influenced by various factors and it is essential to further explore the scientific possibilities to refrain the spread of the parasite among the wild fish population.

Author Contributions: G.K. and M.E.-M. conceptualized and supervised the manuscript. A.S. drafted the manuscript. All authors have read and agreed to the published version of the manuscript.

Funding: This study was funded by the Austrian Science Fund (FWF) Project Number P 30981-B32 to Gokhlesh Kumar.

Acknowledgments: We are thankful to the Austrian Science Fund (FWF) Project Number P $30981-B 32$ for providing Open Access Funding. The first author acknowledges the Indian Council of Agricultural Research, New Delhi, India for providing a PhD scholarship under Netaji Subhas-ICAR International Fellowship 2016-2017.

Conflicts of Interest: The authors declare no conflict of interest.

\section{References}

1. Canning, E.U.; Curry, A.; Feist, S.W.; Longshaw, M.; Okamura, B. Tetracapsula bryosalmonae n.sp. for PKX organism, the cause of PKD in Salmonid fish. Bull. Eur. Assoc. Pathol. 1999, 19, 203-206.

2. Morris, D.J.; Adams, A. Transmission of Tetracapsuloides bryosalmonae (Myxozoa: Malacosporea), the causative organism of salmonid proliferative kidney disease, to the freshwater bryozoan Fredericella sultana. Parasitology 2006, 133, 701-709. [CrossRef] [PubMed]

3. Feist, S.W.; Longshaw, M.; Canning, E.U.; Okamura, B. Induction of proliferative kidney disease (PKD) in rainbow trout Oncorhynchus mykiss via the bryozoan Fredericella sultana infected with Tetracapsula bryosalmonae. Dis. Aquat. Org. 2001, 45, 61-68. [CrossRef]

4. Longshaw, M.; Le Deuff, R.M.; Harris, A.F.; Feist, S.W. Development of proliferative kidney disease in rainbow trout, Oncorhynchus mykiss (Walbaum), following short-term exposure to Tetracapsula bryosalmonae infected bryozoans. J. Fish Dis. 2002, 25, 443-449. [CrossRef]

5. Grabner, D.S.; El-Matbouli, M. Tetracapsuloides bryosalmonae (Myxozoa: Malacosporea) portal of entry into the fish host. Dis. Aquat. Org. 2010, 90, 197-206. [CrossRef] [PubMed]

6. Hedrick, R.P.; MacConnell, E.; de Kinkelin, P. Proliferative kidney disease of salmonid fish. Annu. Rev. Fish Dis. 1993, 3, 277-290. [CrossRef] 
7. Burkhardt-Holm, P.; Giger, W.; Güttinger, H.; Ochsenbein, U.; Peter, A.; Scheurer, K.; Segner, H.; Staub, E.; Suter, M.J.F. Where Have All the Fish Gone? Environ. Sci. Technol. 2005, 39, 441A-447A. [CrossRef]

8. Borsuk, M.E.; Reichert, P.; Peter, A.; Schager, E.; Burkhardt-Holm, P. Assessing the decline of brown trout (Salmo trutta) in Swiss rivers using a Bayesian probability network. Ecol. Model. 2006, 192, 224-244. [CrossRef]

9. Gorgoglione, B.; Kotob, M.H.; Unfer, G.; El-Matbouli, M. First Proliferative Kidney Disease outbreak in Austria, linking to the aetiology of Black Trout Syndrome threatening autochthonous trout populations. Dis. Aquat. Org. 2016, 119, 117-128. [CrossRef]

10. Lewisch, E.; Unfer, G.; Pinter, K.; Bechter, T.; El-Matbouli, M. Distribution and prevalence of T. bryosalmonae in Austria: A first survey of trout from rivers with a shrinking population. J. Fish Dis. 2018, 41, 1549-1557. [CrossRef]

11. Yellowstone River Fish Kill Fact Sheet-Updated. Available online: http://fwp.mt.gov/news/newsReleases/ headlines/nr_4278.html (accessed on 4 October 2019).

12. Sage, J.L. Economic Contributions of the Yellowstone River to Park County, Montana; The Institute for Tourism and Recreation Research: Missoula, MT, USA, 2016.

13. Gay, M.; Okamura, B.; De Kinkelin, P. Evidence that infectious stages of Tetracapsula bryosalmonae for rainbow trout Oncorhynchus mykiss are present throughout the year. Dis. Aquat. Org. 2001, 46, 31-40. [CrossRef] [PubMed]

14. Bettge, K.; Segner, H.; Burki, R.; Schmidt-Posthaus, H.; Wahli, T. Proliferative kidney disease (PKD) of rainbow trout: Temperature- and time-related changes of Tetracapsuloides bryosalmonae DNA in the kidney. Parasitology 2009, 136, 615-625. [CrossRef] [PubMed]

15. Bettge, K.; Wahli, T.; Segner, H.; Schmidt-Posthaus, H. Proliferative kidney disease in rainbow trout: Timeand temperature-related renal pathology and parasite distribution. Dis. Aquat. Org. 2009, 83, 67-76. [CrossRef] [PubMed]

16. Tops, S.; Lockwood, W.; Okamura, B. Temperature-driven proliferation of Tetracapsuloides bryosalmonae in bryozoan portends salmonid declines. Dis. Aquat. Org. 2006, 70, 227-236. [CrossRef]

17. Effects of Elevated Water Temperatures on Salmonids. Available online: https://fortress.wa.gov/ecy/ publications/publications/0010046.pdf (accessed on 30 November 2019).

18. Plehn, M. Praktikum der Fischkrankheiten; Schweizerbart: Stuttgart, Germany, 1924.

19. Roberts, R.J.; Shepherd, C.J. Handbook of Trout and Salmon Diseases; Fishing News (Books) Ltd.: West Byfleet, Surrey, 1974.

20. Kent, M.L.; Hedrick, R.P. PKX, the causative agent of proliferative kidney disease (PKD) in pacific salmonid fishes and its affinities with the Myxozoa. J. Protozool. 1985, 32, 254-260. [CrossRef]

21. Anderson, C.L.; Canning, E.U.; Okamura, B. Molecular data implicate bryozoans as hosts for PKX (Phylum Myxozoa) and identify a clade of bryozoan parasites within the Myxozoa. Parasitology 1999, 119, 555-561. [CrossRef]

22. Canning, E.U.; Curry, A.; Feist, S.W.; Longshaw, M.; Okamura, B. A new class and order of myxozoans to accommodate parasites of bryozoans with ultrastructural observations on Tetracapsula bryosalmonae (PKX organism). J. Eukaryot. Microbiol. 2000, 47, 456-468. [CrossRef]

23. Canning, E.U.; Tops, S.; Curry, A.; Wood, T.S.; Okamura, B. Ecology, development and pathogenicity of Buddenbrockia plumatellae Schröder, 1910 (Myxozoa, Malacosporea) (syn. Tetracapsula bryozoides) and establishment of Tetracapsuloides n. gen. for Tetracapsula bryosalmonae. J. Eukaryot. Microbiol. 2002, 49, 280-295. [CrossRef]

24. Jiménez-Guri, E.; Philippe, H.; Okamura, B.; Holland, P.W.H. Buddenbrockia is a cnidarian worm. Science 2007, 317, 116-118. [CrossRef]

25. Henderson, M.; Okamura, B. The phylogeography of salmonid proliferative kidney disease in Europe and North America. Proc. R. Soc. B Biol. Sci. 2004, 271, 1729-1736. [CrossRef]

26. Hartikainen, H.; Okamura, B. Ecology and evolution of malacosporean-bryozoan interactions. In Myxozoan Evolution, Ecology and Development; Okamura, B., Gruhl, A., Bartholomew, J.L., Eds.; Springer International Publishing: Cham, Germany, 2015; pp. 201-216.

27. Wood, T.S.; Okamura, B. A new key to the freshwater bryozoans of Britain, Ireland and Continental Europe, with notes on their ecology. In Freshwater Biological Association; Sutcliffe, D.W., Ed.; Scientific Publication: Ambleside, UK, 2005; p. 112. 
28. Okamura, B.; Anderson, C.L.; Longshaw, M.; Feist, S.W.; Canning, E.U. Patterns of occurrence and 18s rDNA sequence variation of PKX (Tetracapsula bryosalmonae), the causative agent of salmonid proliferative kidney disease. J. Parasitol. 2001, 87, 379-385. [CrossRef]

29. Hartikainen, H.; Gruhl, A.; Okamura, B. Diversification and repeated morphological transitions in endoparasitic cnidarians (Myxozoa: Malacosporea). Mol. Phylogenet. Evol. 2014, 76, 261-269. [CrossRef] [PubMed]

30. Morris, D.J.; Adams, A. Proliferative, presaccular stages of Tetracapsuloides bryosalmonae (myxozoa: Malacosporea) within the invertebrate host Fredericella sultana (bryozoa: Phylactolaemata). J. Parasitol. 2006, 92, 984-989. [CrossRef] [PubMed]

31. Okamura, B.; Hartikainen, H.; Schmidt-Posthaus, H.; Wahli, T. Life cycle complexity, environmental change and the emerging status of salmonid proliferative kidney disease. Freshw. Biol. 2011, 56, 735-753. [CrossRef]

32. Kent, M.L.; Hedrick, R.P. Transmission of the causative agent of proliferative kidney disease (PKD) with the blood and spleen of infected fish; further evidence that the PKX parasite belongs to the phylum Myxozoa. Bull. Eur. Assoc. Fish Pathol. 1985, 5, 39-42.

33. Morris, D.J.; Adams, A. Sporogony of Tetracapsuloides bryosalmonae in the brown trout Salmo trutta and the role of the tertiary cell during the vertebrate phase of myxozoan life cycles. Parasitology 2008, 135, 1075-1092. [CrossRef]

34. Grabner, D.S.; El-Matbouli, M. Comparison of the susceptibility of brown trout (Salmo trutta) and four rainbow trout (Oncorhynchus mykiss) strains to the myxozoan Tetracapsuloides bryosalmonae, the causative agent of proliferative kidney disease (PKD). Vet. Parasitol. 2009, 165, 200-206. [CrossRef]

35. Kumar, G.; Abd-Elfattah, A.; Saleh, M.; El-Matbouli, M. Fate of Tetracapsuloides bryosalmonae (Myxozoa) after infection of brown trout Salmo trutta and rainbow trout Oncorhynchus mykiss. Dis. Aquat. Org. 2013, 107, 9-18. [CrossRef]

36. Grabner, D.S.; El-Matbouli, M. Transmission of Tetracapsuloides bryosalmonae (Myxozoa: Malacosporea) to Fredericella sultana (Bryozoa: Phylactolaemata) by various fish species. Dis. Aquat. Org. 2008, 79, 133-139. [CrossRef]

37. Soliman, H.; Kumar, G.; El-Matbouli, M. Tetracapsuloides bryosalmonae persists in brown trout Salmo trutta for five years post exposure. Dis. Aquat. Org. 2018, 127, 151-156. [CrossRef]

38. El-Matbouli, M.; Hoffmann, R.W. Influence of water quality on the outbreak of proliferative kidney disease-Field studies and exposure experiments. J. Fish Dis. 2002, 25, 459-467. [CrossRef]

39. Tops, S.; Hartikainen, H.L.; Okamura, B. The effects of infection by Tetracapsuloides bryosalmonae (Myxozoa) and temperature on Fredericella sultana (Bryozoa). Int. J. Parasitol. 2009, 39, 1003-1010. [CrossRef]

40. Burkhardt-Holm, P. Proliferative kidney disease: Why is it of interest for the Swiss project "Fishnet"? J. Fish Dis. 2002, 25, 441-442. [CrossRef]

41. Burkhardt-Holm, P. Decline of brown trout (Salmo trutta) in Switzerland - How to assess potential causes in a multi-factorial cause-effect relationship. Mar. Environ. Res. 2008, 66, 181-182. [CrossRef]

42. Dash, M.; Vasemägi, A. Proliferative kidney disease (PKD) agent Tetracapsuloides bryosalmonae in brown trout populations in Estonia. Dis. Aquat. Org. 2014, 109, 139-148. [CrossRef]

43. Kristmundsson, Á.; Antonsson, T.; Árnason, F. First record of proliferative kidney disease in Iceland. Bull. Eur. Assoc. Fish Pathol. 2010, 30, 35-40.

44. Lahnsteiner, F.; Haunschmid, R.; Mansour, N. Possible reasons for late summer brown trout (Salmo trutta Linnaeus 1758) mortality in Austrian prealpine river systems. J. Appl. Ichthyol. 2011, 27, 83-93. [CrossRef]

45. Wahli, T.; Bernet, D.; Segner, H.; Schmidt-Posthaus, H. Role of altitude and water temperature as regulating factors for the geographical distribution of Tetracapsuloides bryosalmonae infected fishes in Switzerland. J. Fish Biol. 2008, 73, 2184-2197. [CrossRef]

46. Wahli, T.; Bernet, D.; Steiner, P.A.; Schmidt-Posthaus, H. Geographic distribution of Tetracapsuloides bryosalmonae infected fish in Swiss rivers: An update. Aquat. Sci. 2007, 69, 3-10. [CrossRef]

47. Zimmerli, S.; Bernet, D.; Burkhardt-Holm, P.; Schmidt-Posthaus, H.; Vonlanthen, P.; Wahli, T.; Segner, H. Assessment of fish health status in four Swiss rivers showing a decline of brown trout catches. Aquat. Sci. 2007, 69, 11-25. [CrossRef]

48. Jonsson, B.; Jonsson, N. Ecology of Atlantic Salmon and Brown Trout: Habitat as a Template for Life Histories; Springer: Dordrecht, The Netherlands, 2011. 
49. Seagrave, C.P.; Bucke, D.; Hudson, E.B.; Mcgregor, D. A survey of the prevalence and distribution of proliferative kidney disease (PKD) in England and Wales. J. Fish Dis. 1981, 4, 437-439. [CrossRef]

50. Wootten, R.; McVicar, A.H. Some preliminary observations on Proliferative Kidney Disease in wild brown trout, Salmo trutta L. in a Scottish stream. Bull. Eur. Assoc. Fish Pathol. 1982, 2, 60-62.

51. Bucke, D.; Feist, S.W.; Clifton-Hadley, R.S. The occurrence of proliferative kidney disease (PKD) in cultured and wild fish: Further investigations. J. Fish Dis. 1991, 14, 583-588. [CrossRef]

52. Smith, C.E.; Morrison, J.K.; Ramsey, H.W.; Ferguson, H.W. Proliferative kidney disease: First reported outbreak in North America. J. Fish Dis. 1984, 7, 207-216. [CrossRef]

53. Macconnell, E.; Peterson, J.E. Proliferative Kidney Disease in feral cutthroat trout from a remote Montana reservoir: A first case. J. Aquat. Anim. Health 1992, 4, 182-187. [CrossRef]

54. Wahli, T.; Knuesel, R.; Bernet, D.; Segner, H.; Pugovkin, D.; Burkhardt-Holm, P.; Escher, M.; Schmidt-Posthaus, H. Proliferative kidney disease in Switzerland: Current state of knowledge. J. Fish Dis. 2002, 25, 491-500. [CrossRef]

55. Sterud, E.; Forseth, T.; Ugedal, O.; Poppe, T.T.; Jørgensen, A.; Bruheim, T.; Fjeldstad, H.P.; Mo, T.A. Severe mortality in wild Atlantic salmon Salmo salar due to proliferative kidney disease (PKD) caused by Tetracapsuloides bryosalmonae (Myxozoa). Dis. Aquat. Org. 2007, 77, 191-198. [CrossRef]

56. Schmidt-Posthaus, H.; Steiner, P.; Müller, B.; Casanova-Nakayama, A. Complex interaction between proliferative kidney disease, water temperature and concurrent nematode infection in brown trout. Dis. Aquat. Org. 2013, 104, 23-34. [CrossRef]

57. Fontes, I.; Hartikainen, H.; Williams, C.; Okamura, B. Persistence, impacts and environmental drivers of covert infections in invertebrate hosts. Parasites Vectors 2017, 10, 542. [CrossRef]

58. Schmidt-Posthaus, H.; Hirschi, R.; Schneider, E. Proliferative kidney disease in brown trout: Infection level, pathology and mortality under field conditions. Dis. Aquat. Org. 2015, 114, 139-146. [CrossRef]

59. Peeler, E.J.; Feist, S.W.; Longshaw, M.; Thrush, M.A.; St-Hilaire, S. An assessment of the variation in the prevalence of renal myxosporidiosis and hepatitis in wild brown trout, Salmo trutta L., within and between rivers in South-West England. J. Fish Dis. 2008, 31, 719-728. [CrossRef]

60. Mo, T.A.; Jørgensen, A. A survey of the distribution of the PKD-parasite Tetracapsuloides bryosalmonae (Cnidaria: Myxozoa: Malacosporea) in salmonids in Norwegian rivers-Additional information gleaned from formerly collected fish. J. Fish Dis. 2017, 40, 621-627. [CrossRef]

61. Skovgaard, A.; Buchmann, K. Tetracapsuloides bryosalmonae and PKD in juvenile wild salmonids in Denmark. Dis. Aquat. Org. 2012, 101, 33-42. [CrossRef]

62. Braden, L.M.; Prosperi-Porta, G.; Kim, E.; Jones, S.R.M. Tetracapsuloides bryosalmonae in spawning pink salmon, Oncorhynchus gorbuscha (Walbaum), in the Quinsam River, British Columbia, Canada. J. Fish Dis. 2010, 33, 617-621. [CrossRef]

63. Debes, P.V.; Gross, R.; Vasemägi, A. Quantitative genetic variation in, and environmental effects on, pathogen resistance and temperature-dependent disease severity in a wild trout. Am. Nat. 2017, 190, 244-265. [CrossRef]

64. Jenčič, V.; Zajc, U.; Kušar, D.; Ocepek, M.; Pate, M. A survey on Tetracapsuloides bryosalmonae infections in Slovene fresh waters. J. Fish Dis. 2014, 37, 711-717. [CrossRef]

65. Vasemägi, A.; Nousiainen, I.; Saura, A.; Vähä, J.P.; Valjus, J.; Huusko, A. First record of proliferative kidney disease agent Tetracapsuloides bryosalmonae in wild brown trout and European grayling in Finland. Dis. Aquat. Org. 2017, 125, 73-78.

66. Sobociński, B.; Huusko, A.; Vasemägi, A. First record of Tetracapsuloides bryosalmonae (Myxozoa; Malacosporea) in European whitefish (Coregonus lavaretus). Bull. Eur. Assoc. Fish Pathol. 2018, 38, 115-120.

67. Boyer, J.K. Spawning and Early Life History of Mountain Whitefish in the Madison River, Montana. Ph.D. Thesis, Montana State University, Bozeman, MT, USA, 2016.

68. De Kinkelin, P.; Gerald, J.P. Reunion sur l'hepatonephrite parasitaire de la Truite Arc-en-Ciel. In Bulletin de l'Office International des Epizooties; Office International des Épizooties: Paris, France, 1977; Volume 87, pp. 489-490.

69. Sawyer, T.K.; Ghittion, P. Proliferative Kidney Disease in Rainbow Trout From Italian Hatcheries; International Association for Aquatic Animal Medicine Proceedings: Baltimore, MD, USA, 1982.

70. Beraldo, P.; Berton, D.; Giavenni, R.; Galeotti, M. First report on proliferative kidney disease (PKD) in marble trout (Salmo trutta marmoratus, Cuvier 1817). Bull. Eur. Assoc. Fish Pathol. 2006, 26, 143-150. 
71. Peribáñez, M.A.; Luco, D.F.; García, L.; Castillo, J.A. The prevalence of proliferative kidney disease from the kidney and muscle of rainbow and brown trout in Aragon (Spain). Prev. Vet. Med. 1997, 32, 287-297.

72. Quigley, D.T.G.; McArdle, J.F. Management and control of proliferative kidney disease (PKD) in a freshwater Atlantic salmon (Salmo salar L.) farm in Ireland: A case history. Fish Vet. J. 1988, 2, 1-12.

73. Palikova, M.; Papezikova, I.; Markova, Z.; Navratil, S.; Mares, J.; Mares, L.; Vojtek, L.; Hyrsl, P.; Jelinkova, E.; Schmidt-Posthaus, H. Proliferative kidney disease in rainbow trout (Oncorhynchus mykiss) under intensive breeding conditions: Pathogenesis and haematological and immune parameters. Vet. Parasitol. 2017, 238, 5-16. [CrossRef]

74. Kumar, G.; Abd-Elfattah, A.; Soliman, H.; El-Matbouli, M. Establishment of medium for laboratory cultivation and maintenance of Fredericella sultana for in vivo experiments with Tetracapsuloides bryosalmonae (Myxozoa). J. Fish Dis. 2013, 36, 81-88. [CrossRef]

75. Hutchins, P.R.; Sepulveda, A.J.; Martin, R.M.; Hopper, L.R. A probe-based quantitative PCR assay for detecting Tetracapsuloides bryosalmonae in fish tissue and environmental DNA water samples. Conserv. Genet. Resour. 2018, 10, 317-319. [CrossRef]

76. Fontes, I.; Hartikainen, H.; Holland, J.; Secombes, C.; Okamura, B. Tetracapsuloides bryosalmonae abundance in river water. Dis. Aquat. Org. 2017, 124, 145-157. [CrossRef]

77. Soliman, H.; Kumar, G.; El-Matbouli, M. Recombinase polymerase amplification assay combined with a lateral flow dipstick for rapid detection of Tetracapsuloides bryosalmonae, the causative agent of proliferative kidney disease in salmonids. Parasites Vectors 2018, 11, 234. [CrossRef]

78. Kent, M.L.; Higgins, M.; Whitaker, D.J.; Yokoyama, H. Proliferative kidney disease and Sphaerospora oncorhynchi in wild-caught salmonids from the Puntledge river system, Vancouver-Island, British-Columbia. Can. J. Fish. Aquat. Sci. 1995, 52, 13-17. [CrossRef]

79. Feist, S.W.; Peeler, E.J.; Gardiner, R.; Smith, E.; Longshaw, M. Proliferative kidney disease and renal myxosporidiosis in juvenile salmonids from rivers in England and Wales. J. Fish Dis. 2002, 25, 451-458. [CrossRef]

80. Gorgoglione, B.; Bailey, C.; Ferguson, J.A. First report of Tetracapsuloides bryosalmonae and PKD in Alaskan salmonids. In Proceedings of the 44th Annual Eastern Fish Health Workshop, New York, NY, USA, 1-5 April 2019; p. 20.

81. Arndt, D.; Fux, R.; Blutke, A.; Schwaiger, J.; El-Matbouli, M.; Sutter, G.; Langenmayer, M.C. Proliferative kidney disease and proliferative darkening syndrome are linked with brown trout (Salmo trutta fario) mortalities in the Pre-Alpine Isar river. Pathogens 2019, 8, 177. [CrossRef]

82. Altizer, S.; Ostfeld, R.S.; Johnson, P.T.J.; Kutz, S.; Harvell, C.D. Climate change and infectious diseases: From evidence to a predictive framework. Science 2013, 341, 514-519. [CrossRef]

83. Marcogliese, D.J. The distribution and abundance of parasites in aquatic ecosystems in a changing climate: More than just temperature. Integr. Comp. Biol. 2016, 56, 611-619. [CrossRef]

84. Bailey, C.; Schmidt-Posthaus, H.; Segner, H.; Wahli, T.; Strepparava, N. Are brown trout Salmo trutta fario and rainbow trout Oncorhynchus mykiss two of a kind? A comparative study of salmonids to temperature-influenced Tetracapsuloides bryosalmonae infection. J. Fish Dis. 2018, 191-198. [CrossRef]

85. De Kinkelin, P.; Loriot, B. A water temperature regime which prevents the occurrence of proliferative kidney disease (PKD) in rainbow trout, Oncorhynchus mykiss (Walbaum). J. Fish Dis. 2001, 24, 489-493. [CrossRef]

86. Foott, J.S.; Hedrick, R.P. Seasonal occurrence of the infectious stage of proliferative kidney disease (PKD) and resistance of rainbow trout, Salmo gairdneri Richardson, to reinfection. J. Fish Biol. 1987, 30, 477-483. [CrossRef]

87. Clifton-Hadley, R.S.; Bucke, D.; Richards, R. Proliferative kidney disease of salmonid fish: A review. J. Fish Dis. 1984, 7, 363-377. [CrossRef]

88. Hartikainen, H.; Johnes, P.; Moncrieff, C.; Okamura, B. Bryozoan populations reflect nutrient enrichment and productivity gradients in rivers. Freshw. Biol. 2009, 54, 2320-2334. [CrossRef]

89. Le Morvan, C.; Troutaud, D.; Deschaux, P. Differential effects of temperature on specific and nonspecific immune defences in fish. J. Exp. Biol. 1998, 201, 165-168.

90. Köllner, B.; Kotterba, G. Temperature dependent activation of leucocyte populations of rainbow trout, Oncorhynchus mykiss, after intraperitoneal immunisation with Aeromonas salmonicida. Fish Shellfish Immunol. $2002,12,35-48$. 
91. Nikoskelainen, S.; Bylund, G.; Lilius, E.M. Effect of environmental temperature on rainbow trout (Oncorhynchus mykiss) innate immunity. Dev. Comp. Immunol. 2004, 28, 581-592. [CrossRef]

92. Abram, Q.H.; Dixon, B. Impacts of low temperature on the teleost immune system. Biology 2017, 6, 39. [CrossRef]

93. Chilmonczyk, S.; Monge, D.; De Kinkelin, P. Proliferative kidney disease: Cellular aspects of the rainbow trout, Oncorhynchus mykiss (Walbaum), response to parasitic infection. J. Fish Dis. 2002, 25, 217-226. [CrossRef]

94. Schmidt-Posthaus, H.; Bettge, K.; Forster, U.; Segner, H.; Wahli, T. Kidney pathology and parasite intensity in rainbow trout Oncorhynchus mykiss surviving proliferative kidney disease: Time course and influence of temperature. Dis. Aquat. Org. 2012, 97, 207-218. [CrossRef]

95. Macconnell, E.; Smith, C.E.; Hedrick, R.P.; Speer, C.A. Cellular inflammatory response of rainbow trout to the protozoan parasite that causes proliferative kidney disease. J. Aquat. Anim. Health 1989, 1, 108-118. [CrossRef]

96. Bailey, C.; Segner, H.; Casanova-Nakayama, A.; Wahli, T. Who needs the hotspot? The effect of temperature on the fish host immune response to Tetracapsuloides bryosalmonae the causative agent of proliferative kidney disease. Fish Shellfish Immunol. 2017, 63, 424-437. [CrossRef]

97. Abos, B.; Estensoro, I.; Perdiguero, P.; Faber, M.; Hu, Y.; Rosales, P.D.; Granja, A.G.; Secombes, C.J.; Holland, J.W.; Tafalla, C. Dysregulation of B cell activity during proliferative kidney disease in rainbow trout. Front. Immunol. 2018, 9, 1203. [CrossRef]

98. Bruneaux, M.; Visse, M.; Gross, R.; Pukk, L.; Saks, L.; Vasemägi, A. Parasite infection and decreased thermal tolerance: Impact of proliferative kidney disease on a wild salmonid fish in the context of climate change. Funct. Ecol. 2017, 31, 216-226. [CrossRef]

99. Bailey, C.; Strepparava, N.; Wahli, T.; Segner, H. Exploring the immune response, tolerance and resistance in proliferative kidney disease of salmonids. Dev. Comp. Immunol. 2019, 90, 165-175. [CrossRef]

100. Kumar, G.; Abd-Elfattah, A.; El-Matbouli, M. Identification of differentially expressed genes of brown trout (Salmo trutta) and rainbow trout (Oncorhynchus mykiss) in response to Tetracapsuloides bryosalmonae (Myxozoa). Parasitol. Res. 2015, 114, 929-939. [CrossRef]

101. Sudhagar, A.; Ertl, R.; Kumar, G.; El-Matbouli, M. Transcriptome profiling of posterior kidney of brown trout, Salmo trutta, during proliferative kidney disease. Parasites Vectors 2019, 12, 569. [CrossRef]

102. Bailey, C.; von Siebenthal, E.W.; Rehberger, K.; Segner, H. Transcriptomic analysis of the impacts of ethinylestradiol (EE2) and its consequences for proliferative kidney disease outcome in rainbow trout (Oncorhynchus mykiss). Comp. Biochem. Physiol. Part C Toxicol. Pharmacol. 2019, 222, 31-48. [CrossRef]

103. Figuerola, J.; Green, A.J. Dispersal of aquatic organisms by waterbirds: A review of past research and priorities for future studies. Freshw. Biol. 2002, 47, 483-494. [CrossRef]

104. Abd-Elfattah, A.; El-Matbouli, M.; Kumar, G. Structural integrity and viability of Fredericella sultana statoblasts infected with Tetracapsuloides bryosalmonae (Myxozoa) under diverse treatment conditions. Vet. Res. 2017, 48, 19. [CrossRef] [PubMed]

105. Stuart, I.G.; Jones, M.J. Movement of common carp, Cyprinus carpio, in a regulated lowland Australian river: Implications for management. Fish. Manag. Ecol. 2006, 13, 213-219. [CrossRef]

106. Abd-Elfattah, A.; Fontes, I.; Kumar, G.; Soliman, H.; Hartikainen, H.; Okamura, B.; El-Matbouli, M. Vertical transmission of Tetracapsuloides bryosalmonae (Myxozoa), the causative agent of salmonid proliferative kidney disease. Parasitology 2014, 141, 482-490. [CrossRef]

107. Garner, M.G.; Hamilton, S.A. Principles of epidemiological modelling. Rev. Sci. Tech. Off. Int. Epiz. 2011, 30, 407-416. [CrossRef]

108. Carraro, L.; Mari, L.; Hartikainen, H.; Strepparava, N.; Wahli, T.; Jokela, J.; Gatto, M.; Rinaldo, A.; Bertuzzo, E. An epidemiological model for proliferative kidney disease in salmonid populations. Parasites Vectors 2016, 9, 487. [CrossRef]

109. Carraro, L.; Bertuzzo, E.; Mari, L.; Fontes, I.; Hartikainen, H.; Strepparava, N.; Schmidt-Posthaus, H.; Wahli, T.; Jokela, J.; Gatto, M.; et al. Integrated field, laboratory, and theoretical study of PKD spread in a Swiss prealpine river. Proc. Natl. Acad. Sci. USA 2017, 114, 11992-11997. [CrossRef]

110. Carraro, L.; Mari, L.; Gatto, M.; Rinaldo, A.; Bertuzzo, E. Spread of proliferative kidney disease in fish along stream networks: A spatial metacommunity framework. Freshw. Biol. 2018, 63, 114-127. [CrossRef] 
(C) 2019 by the authors. Licensee MDPI, Basel, Switzerland. This article is an open access article distributed under the terms and conditions of the Creative Commons Attribution (CC BY) license (http://creativecommons.org/licenses/by/4.0/). 